\title{
Macro- and microelements occurence in soil and plant (leaves) samples of a representative and potentially sustainable Mediterranean vineyard
}

\author{
RAIMUNDO JIMENEZ-BALLESTA ${ }^{1}$, Sandra Bravo $^{2}$, Caridad Pérez de los Reyes ${ }^{3}$, JOSE \\ A. AMOROS ${ }^{2}$, Jesus Garcia-Pradas ${ }^{2}$, Monica Sánchez ${ }^{2}$, and FRANCISCO \\ GARCIA-NAVARRO ${ }^{2}$ \\ ${ }^{1}$ UNIVERSIDAD AUTONOMA \\ ${ }^{2}$ Universidad de Castilla-La Mancha \\ ${ }^{3} \mathrm{UCLM}$
}

November 26, 2020

\begin{abstract}
The study reported here concerns the geochemical distributions of macro- and trace elements (including potentially toxic elements, PTEs) in the vineyard soils of Alcubillas, which is one of the oldest, albeit not world-reknowned, wine-growing areas in La Mancha (Central Spain). Soil and leaf samples were analyzed by X-ray fluorescence spectrometry to ascertain the levels of various elements in the soil and the plant. The potential toxicity of the elements was assessed with regard to the development of the vineyard. Despite the fact that fertilizers and pesticides are employed in the vineyards in this area, the results showed that the levels of trace elements in the soil samples did not exceed the reference values according the pedogeochemical values for the region and Spain. This finding suggests that the study area is not polluted. The Biological Absortion Coefficient (BAC) was calculated to assess the assimilation of various elements from the soil to the leaves, and differences were found in the element absorption capacity of the vines. Some elements were not taken up by Vitis vinifera despite elements like $\mathrm{Zr}$ and $\mathrm{Rb}$ being present in relatively high concentrations in the soil. The production in these soils of grapes and wine does not represent a threat to human health or the ecosystem, because the farmers in this area are extremely careful to preserve the environment and they only farm to achieve moderate yields of grapes per hectare.
\end{abstract}

\section{Introduction}

Soil is an important part of the natural environment and its effect on wine quality and grape composition is highly complex because it has an influence on mineral nutrition in the grapevine, the uptake of water, root depth and rhizosphere temperature. In this respect, analysis of elements could be used (Greenough et al. 2005) since it is believed that these chemical elements present in the soil can be transferred to the plant and subsequently to the harvested grapes (Protano and Rossi 2014). The topic, however, is now being discussed further because it has not been demonstrated how these elements act on the sensory attributes of wines (Maltman 2013).

In viticulture, micronutrient deficiencies are corrected by the addition of trace elements that are essential for plant growth, e.g., $\mathrm{Cu}, \mathrm{Zn}, \mathrm{Fe}, \mathrm{Mn}$ and $\mathrm{B}$. Treatment of plants with fungicides, pesticides and herbicides also inputs chemicals into the vineyard soil. However, the presence of trace elements of natural origin in grapes and wine is mainly dependent on the mineralogical content of the soils, which are developed from various types of rocks.

Trace elements, including potentially toxic elements (PTEs, Hooda 2010), are found naturally in soils and 
they can also be introduced and accumulated due to anthropogenic influences in agricultural, urban and industrial areas. The extensive use of fertilizers and fungicides (Kment et al. 2005; Komárek et al. 2010; Geana et al. 2013; Wightwick et al. 2013) leads to the accumulation of trace elements in vineyard soils and the bioavailability of such elements may be increased for plants. Other sources of trace elements include industrial pollution of sites (Moreno et al. 2007; Pohl 2007; Geana et al. 2013). It is not surprising, therefore, that numerous studies on viticultural areas have focused on the identification of the main macro- and microelements in the soil, grapes and wine (Huzum et al. 2012; Bora et al. 2013, 2015; Geana et al. 2013; Ungureanu et al. 2017).

The probability of anthropogenic contamination and the toxicological health risks associated with soil pollution can be evaluated by considering various indices (Mehr et al. 2017). Indeed, trace element data can be used, through predictive indices (such as the enrichment factor EF or Geocumulation Index, I-geo), to evaluate risks based on their total contents and toxicity (Gu et al. 2016; Müller 1969). On the other hand, the bioaccumulation coefficient (BAC) provides information about the capacity of a plant to uptake nutrients and this parameter can be measured in any plant tissue (root, leaf or fruit) (Kabata-Pendias 2001).

Although terroir studies have generally focused on heavily populated regions, a few studies have been conducted in smaller rural locations. In this respect, the objectives of this study were to provide an overview of the contents of some major and trace elements (including PTEs) in vineyard soils in a small and traditional rural location, namely Alcubillas (a small municipality of La Mancha, Central Spain), with special attention paid to those elements that under particular environmental circumstances may become toxic. The specific goals were (i) to provide a database for the studied macro- and microelements, (ii) to establish an ecological risk assessment for some PTEs in order to contribute to sustainable management of this agricultural area and (iii) to determine if certain elements are present in significant quantities in grapevine leaves in relation to soil composition.

\section{Material and methods}

\section{Study area}

The study area of Alcubillas is in the Castilla-La Mancha Community in Central Spain (Figure 1). The coordinates of this site are $38^{\circ} 45^{\prime} 7^{\prime \prime} \mathrm{N}$ and $3^{\circ} 8^{\prime} 5^{\prime} \mathrm{W}$ and the area is 4,768 ha. The main crops that are cultivated in Alcubillas are vines, olive trees and cereals. There are also some small plots dedicated to orchards.

One of the main physiographic features is a virtually flat and karstified surface that is interrupted by residual reliefs in the form of inselberg and an alluvial plain. The major parent materials are calcareous sediments, limestones (with signs of karstification, as evidenced by the appearance of numerous 'dolinas'), clay sediments of fluvial character, and quartzite sandstones (in some cases slates) in residual surfaces of the Paleozoic era. At this site the majority of the soils are Alfisols, Inceptisols and Entisols according to Soil Taxonomy (Soil Survey Staff 2014) and Luvisols, Calcisols, Cambisols, Regosols and Leptsols according to FAO-UNESCOISSS (2006). The dominant formation is constitued by Red soils (Alfisols) with calcic or petrocalcic horizons (Jiménez-Ballesta et al. 2020).

\section{Figure 1}

\section{Sampling and laboratory methods}

Soil samples from 10 profiles and 12 superficial horizons were collected. The sampling locations were selected from different geomorphological sites and vineyard types. Given that the majority of the active vine roots are located at a depth of 20-80 cm, the samples were taken from the Ap and Bt or Bw horizons. Leaf samples were collected along with the soil on which the plants were growing. The samples were air-dried naturally and sieved through a $2-\mathrm{mm}$ sieve to remove the coarse fraction. The remaining fine-earth fraction was homogenized before chemical analysis was carried out. The contents of major and trace elements (Na, Mg, Al, Si, P, S, K, Ca, Fe, Mn, Ti, Ba, Sr, V, Cr, Ce, Rb, Ni, Zn, Nd, Pb, Nb, Co, Cs, Ga, La, Y, Zr, Sc, $\mathrm{Th}, \mathrm{U}, \mathrm{Sn}, \mathrm{Cu}, \mathrm{As}, \mathrm{Mo}, \mathrm{Ta}, \mathrm{Hf}$ and $\mathrm{W}$ ) in the soil and leaf samples were determined by X-ray fluorescence 
spectroscopy (XRF) using a Philips PW 2404 spectrophotometer with a maximum power of $4 \mathrm{~kW}$ (set of crystal analysers for LiF220, LiF200, Ge, PET and PX1, flow detector and twinkle detector). This analytical technique has been validated for solid matrices such as sediment (Stosnach and Mages 2009; Pessanha et al. 2010). Quality control was ensured by duplicate analysis of certified reference samples (BCR 62, SMR 1573A, SMR 1515).

\section{Statistical analysis}

The data were analyzed using Microsoft Office Excel 2018 and the software Statistical Package for Social Science (SPSS 24.0 for Windows, SPSS Inc., IL, U.S.A.), both under institutional licenses for the University of Castilla-La Mancha (Spain).

Pollution indices: Geocumulation Index (I-geo)

The level of contamination in sediments is commonly assessed and quantified using the so-called geoaccumulation (Igeo) parameter. This was originally defined by Müller (1969) and is obtained using the formula:

[1]

where $C_{n}$ denotes the measured value and $B_{n}$ is the geochemical background of the site. The factor 1.5 is applied to control variations in $B_{n}$ values caused by anthropogenic influences. The geo-accumulation index (Igeo) was defined into seven classes (Table 1) by Buccolieri et al. (2006).

\section{Table 1}

Biological Absortion Coefficient (BAC)

The BAC is the ratio between the plant and soil concentrations of each element. In this study the concentration in the leaf was used.

$B A C=\frac{[\text { leaf }]}{[\text { soil }]}[2]$

\section{Results and Discussion}

Macroelement contents in soils

The results of macroelement measurements are summarized as mean, standard deviation (SD), minimum, and maximum values (Table 2).

\section{Table 2}

The vineyard soils from the Alcubillas site showed a heterogeneous concentration for the elemental composition (Table 2), with Si and Ca being the most abundant major elements followed by Al, influenced by the parent rock. The average soil cointents in Ca were $134.4 \mathrm{~g}^{*} \mathrm{~kg}^{-1}$ in topsoil (Ap horizons) and $161.6 \mathrm{~g}^{\mathrm{kg}} \mathrm{kg}^{-1}$ in subsoil (B horizons). These values (that highlight the calcaric character of the studied soils) are higher than the global average ( $15 \mathrm{~g}^{*} \mathrm{~kg}^{-1}$, Kabata Pendias 2011 and other authors); in some case the Ca content even reached values up to $412.7 \mathrm{~g}^{*} \mathrm{~kg}^{-1}$. It is worth pointing out that there are wine areas in the world with similar contents in Ca and many of these are highly appreciated for their wines. This is the case, for example, in the Champagne and Burgundy regions in France, Tuscany in Italy, and La Rioja in Spain.

Iron $(\mathrm{Fe})$ and potassium $(\mathrm{K})$ are present at lower levels that Ca. Iron - the average content of which in both horizons was $32.3 \mathrm{~g}^{*} \mathrm{~kg}^{-1}$ - is necessary for the formation of chlorophyll, the respiration process of plants and the formation of certain proteins. The value for sulfur (S) obtained in the study area is $0.6 \mathrm{~g}^{*} \mathrm{~kg}^{-1}$, a value below the average world background level $\left(0.70 \mathrm{~g}^{*} \mathrm{~kg}^{-1}\right.$, Kabata-Pendias 2011).

The variances in the $\mathrm{Si}$ and $\mathrm{Ca}$ values are very large, while $\mathrm{Na}, \mathrm{Mg}, \mathrm{S}, \mathrm{P}$ and $\mathrm{Mn}$ showed low variance. These variations can be explained as being the result of soil evolution and, to a lesser extent, ploughing and agricultural practices, as reported by Mirlean et al. (2007). Manganese (Mn) concentrations varied very little in the soils in the study area (between 0.7 and $0.6 \mathrm{~g}^{*} \mathrm{~kg}^{-1}$ ). 


\section{Trace element contents in soils}

The results of microelemental measurements are summarized as mean, standard deviation (SD), minimum, and maximum values (Table 3).

\section{Table 3}

The data reported in Table 3 allow some general observations to be made. These data and the behaviour of some elements is discussed below.

Copper (Cu) and zinc ( $\mathrm{Zn})$

Copper is also one of the most widely studied elements in wine-growing regions because the treatment and prevention of vine downy mildew is commonly carried out using the Bordeaux mixture $\left(\mathrm{Ca}(\mathrm{OH})_{2}+\mathrm{CuSO}_{4}\right)$. However, copper becomes toxic to plants and some micro-organisms when it is present at high levels in soils as it disrupts nutrient-cycling and inhibits the mineralisation of essential nutrients.

In the soils under discussion here, copper was present in an acceptable medium level (Table 3), i.e., between $25.0 \mathrm{mg}^{*} \mathrm{~kg}^{-1}$ (topsoil) and $23.7 \mathrm{mg}^{*} \mathrm{~kg}^{-1}$ (subsoil). The world average level in soil is $30 \mathrm{mg}^{*} \mathrm{~kg}^{-1}$ (from 2 to $250 \mathrm{mg}^{*} \mathrm{~kg}^{-1}$, Adriano 2001) and the normal variation in soils is between $5 \mathrm{mg}^{*} \mathrm{~kg}^{-1} \mathrm{and}^{-1} \mathrm{mg}^{*} \mathrm{~kg}^{-1}$ (Bloemen et al. 1995). A mean value of $35.4 \mathrm{mg}^{*} \mathrm{~kg}^{-1}$ has been determined in Spain (Peris et al. 2007), $24 \mathrm{mg}^{*} \mathrm{~kg}^{-1}$ (from 1 to $111 \mathrm{mg}^{*} \mathrm{~kg}^{-1}$ ) in Portugal (Reis et al. 2007), $227 \mathrm{mg}^{*} \mathrm{~kg}^{-1}$ in France for the deep horizon (Chopin et al. 2008), while in Brazil the content is in the range from $50.1 \mathrm{mg}^{*} \mathrm{~kg}^{-1}$ (20 years) to $2197 \mathrm{mg}^{*} \mathrm{~kg}^{-1}$ (100 years) (Mirlean et al. 2007). The pedogeochemical baseline level for Castilla-La Mancha is $10.3 \mathrm{mg}^{*} \mathrm{~kg}^{-1}$ (Jimenez- Ballesta et al. 2010).

The average contents in $\mathrm{Zn}$ (Table 3) are $47.4 \mathrm{mg}^{*} \mathrm{~kg}^{-1}$ (topsoil) and $43.6 \mathrm{mg}^{*} \mathrm{~kg}^{-1}$ (subsoil). According to other authors the values for Zn range between $10 \mathrm{mg}^{*} \mathrm{~kg}^{-1}$ and $300 \mathrm{mg}^{*} \mathrm{~kg}^{-1}$ (Adriano 2001), with a world soil average of $50 \mathrm{mg}^{*} \mathrm{~kg}^{-1}$, so contamination is not evident for this element. In Castellon (Spain) the average value is $76.8 \mathrm{mg}^{*} \mathrm{~kg}^{-1}$ (Peris et al. 2007); in the Champagne region of France (Chopin et al. 2008) the values range from $318 \mathrm{mg}^{*} \mathrm{~kg}^{-1}$ in the topsoil to $208 \mathrm{mg}^{*} \mathrm{~kg}^{-1}$ in the deep horizon, with $75 \mathrm{mg}^{*} \mathrm{~kg}^{-1}$ as median; and in Portugal (Reis et al. 2007) a minimum value of $14 \mathrm{mg}^{*} \mathrm{~kg}^{-1}$ and a maximum value of $344 \mathrm{mg}^{*} \mathrm{~kg}^{-1}$ were determined for vineyard areas. Finally, the pedogeochemical baseline level for Castilla-La Mancha (Central Spain) is $35.7 \mathrm{mg}^{*} \mathrm{~kg}^{-1}$ (Jimenez Ballesta et al. 2010). Increased concentrations of $\mathrm{Zn}$ and $\mathrm{Cu}$ in soils under the long-term production of grapevine have been recorded in numerous studies (Romić and Romić 2003; Fishel 2014; Tóth et al. 2016).

Lead (Pb), cobalt (Co) and chromium ( $\mathrm{Cr}$ )

In the vineyard soils studied, lead $(\mathrm{Pb})$ has average values (Table 3 ) of $21.9 \mathrm{mg}^{-\mathrm{kg}^{-1}}$ in topsoil and 20.2 $\mathrm{mg} \cdot \mathrm{kg}^{-1}$ in subsoil. In some cases moderately high Pb levels $\left(31.6 \mathrm{mg} \cdot \mathrm{kg}^{-1}\right)$ are detected in some soils when compared to the pedogeochemical baseline levels for Castilla-La Mancha (19.3 mg. $\mathrm{kg}^{-1}$, Jiménez Ballesta et al. 2010). This level is probably caused by the mechanized equipment used for works carried out in the vineyard. However, these values are still far below the total mean contents of other regions. For example, the lead content in Castellon, Spain, is $56.1 \mathrm{mg} \cdot \mathrm{kg}^{-1}$ (Peris et al. 2007), in the Champagne region of France $\mathrm{Pb}$ ranges from 76 (deep horizon) to $141 \mathrm{mg} \cdot \mathrm{kg}^{-1}$ (topsoil) (Chopin et al. 2008) and, in the case of the soils from Brestnik village, (Bulgaria), values range from $72.6 \mathrm{mg} \cdot \mathrm{kg}^{-1}$ for a depth of $0-10 \mathrm{~cm} \mathrm{to} 61.4 \mathrm{mg} \cdot \mathrm{kg}^{-1}$ (Huzum et al. 2012).

In the present study, the chromium (Cr) content is in the range between 71.0 and $29.9 \mathrm{mg}^{\circ} \cdot \mathrm{kg}^{-1}\left(\mathrm{Table}^{3}\right)$, with an average of $51.4 \mathrm{mg} \cdot \mathrm{kg}^{-1}$, in top horizons, whereas in the subsoil the values range between 70.9 and $25.5 \mathrm{mg} \cdot \mathrm{kg}^{-1}$, with an average of $50.0 \mathrm{mg} \cdot \mathrm{kg}^{-1}$. The chromium contents in soils worldwide differ greatly, i.e., in the range from 7 to $2221 \mathrm{mg} \cdot \mathrm{kg}^{-1}$ (McBride 1994), and this depends mostly on the parent material and soil mineralogy. Mîrlean et al. (2007) suggested a variation between 8.2 (young plantation) and $77.9 \mathrm{mg} \cdot \mathrm{kg}^{-1}$. In Portugal the $\mathrm{Cr}$ content has an average of $31 \mathrm{mg} \cdot \mathrm{kg}^{-1}$ (from a minimum of 3 to a maximum value of 243 $\mathrm{mg} \cdot \mathrm{kg}^{-1}$ ) (Reis et al. 2007), while the values for some areas in Spain are quite similar, with a total mean 
content of $32.2 \mathrm{mg} \cdot \mathrm{kg}^{-1}$ (Peris et al. 2007). With some exceptions, the chromium concentrations did not exceed the pedogeochemical baseline value for soils of Castilla-La Mancha (Jiménez Ballesta et al. 2010).

The average cobalt (Co) content is near to $10.5 \mathrm{mg} \cdot \mathrm{kg}^{-1}$ (Table 3 ) for both topsoil and subsoil, with values slightly higher than for the soils of Castilla-La Mancha (5.8 $\mathrm{mg} \cdot \mathrm{kg}^{-1}$, Jiménez Ballesta et al. 2010). Cobalt is an element that is essential to human health but excess amounts can cause detrimental effects (ATSDR 2004). The transfer potential from soil to the edible parts of plants is rather low (Luo et al. 2010).

The total average nickel (Ni) contents (Table 3) in the topsoil and subsoil of Alcubillas are similar (34.7 vs $33.9 \mathrm{mg} \cdot \mathrm{kg}^{-1}$, respectively). In terms of Ni values, a total mean content of $19.9 \mathrm{mg} \cdot \mathrm{kg}^{-1}$ was reported for the Castellon area of Spain (Peris et al. 2007) and a mean value of $28 \mathrm{mg} \cdot \mathrm{kg}^{-1}$ (with a minimum of $2 \mathrm{mg} \cdot \mathrm{kg}^{-1}$ and a maximum of $539 \mathrm{mg} \cdot \mathrm{kg}^{-1}$ ) was found in the Douro basin, Portugal (Reis et al. 2007). The levels of Ni in Alcubillas are slightly higher than the current Castilla-La Mancha pedogeochemical reference value (16.9 $\left.\mathrm{mg} \cdot \mathrm{kg}^{-1}\right)$.

Strontium (Sr) and Molybdenum (Mo)

The contents of strontium in the surface and subsurface horizons are $125.9 \mathrm{mg} \cdot \mathrm{kg}^{-1}$ (Table 3). The mean worldwide background concentration for $\mathrm{Sr}$ in soil is $147.9 \mathrm{mg} \cdot \mathrm{kg}^{-1}$ (Kabata-Pendias 2011) and in Castilla-La Mancha it is $380.0 \mathrm{mg} \cdot \mathrm{kg}^{-1}$, although in this Community values of up to $3384.9 \mathrm{mg} \cdot \mathrm{kg}^{-1}$ have been found in soils on gypsum or gypsum marls (Conde et al. 2008). Alcubillas is an active agricultural area and therefore the levels determined cannot be attributed to the use of soil amendments (e.g., phosphorus fertilizers). Various anthropogenic activities, including the application of fertilizers, the generation of nuclear power, and the burning of coal to generate power, have led to increased levels of strontium (Sr) in soil (Burger and Lichtscheidl 2019). The great potential for the accumulation of $\mathrm{Sr}$ in plants and animals can pose serious environmental and human health hazards, which include cancers and disorders of the nervous system (Burger and Lichtscheidl 2019). The average $\mathrm{Sr}$ contents in some materials commonly used in agriculture include 80.9 $\mathrm{mg} \cdot \mathrm{kg}^{-1}$ in manure, $75.9 \mathrm{mg} \cdot \mathrm{kg}^{-1}$ in sewage sludge, and $270.9 \mathrm{mg} \cdot \mathrm{kg}^{-1}$ in industrial sludge (Munthali et al. 2015). Phosphate fertilizers can also act as a local source of Sr contamination in soil (Abdi et al. 2015). It is worth highlighting that all $\mathrm{Sr}$ concentrations for all soil types in this study were below the background value, thus indicating that there is no $\mathrm{Sr}$ pollution in the study area.

Molybdenum is involved as a micronutrient anion in various physiological and enzymatic processes in plants (Mishra et al. 2006) and humans (Schwarz and Belaidi 2013). Sr is able to affect the health of plants and animals because in high concentrations it is a potentially toxic metal (Evans and Barabash 2010). The average Mo content in the surface soils of Alcubillas was $0.9 \mathrm{mg} \cdot \mathrm{kg}^{-1}$ and in the subsurface soils it was 1.0 $\mathrm{mg} \cdot \mathrm{kg}^{-1}$ (Table 3), with a maximum level of $1.3 \mathrm{mg} \cdot \mathrm{kg}^{-1}$. In comparison to the pedogechemical references for Castilla-La Mancha these values are lower or similar and they are also lower than the mean background content of Mo in surface soils as a worldwide average $\left(1.1 \mathrm{mg} \cdot \mathrm{kg}^{-1}\right.$, Kabata-Pendias 2011).

\section{Ecological risk assessment}

The pollution index (I-geo) provides a useful tool to evaluate potential environmental contamination. On considering the I-geo (Table 3 ) values it can be observed that all values fall in the 0 class, which indicates the absence of contamination, i.e. almost all of the elements are of natural origin or from natural weathering processes. Only $\mathrm{Cu}, \mathrm{Ni}$ and $\mathrm{Co}$ fall into the class 1 category and these elements are therefore influenced slightly by human activity.

Trace element contents in leaves. Soil/leaf ratios

For primary production through photosynthesis, in addition to water and carbon dioxide, plants require some inorganic mineral nutrients that are taken up through the root system. In this process elements are transferred from soil to plant and the leaf mineral composition should reflect the complex interaction between Vitis vinifera and the local soil composition, since it is one of main factors that limits plant productivity and quality. The Biological Absorption Coefficient (BAC) is the bioaccumulation of a given element and this is 
the ratio between the leaf/soil concentrations (Kabatha-Pendias 2003). The BAC values are listed in Table 4 .

The modified Kabata-Pendias BAC classification (2001) was used here to classify the major elements accumulated in the vine leaf. The elements $\mathrm{Ca}, \mathrm{K}, \mathrm{Mg}$ and $\mathrm{S}$ had high $\mathrm{BAC}$ values (greater than 1), whereas $\mathrm{Sr}$ and $\mathrm{Zn}$ had medium $\mathrm{BAC}$ values (between 0.4 and 0.7 ) and $\mathrm{Ba}, \mathrm{Pb}, \mathrm{Cu}$ had low values (between 0.4 and $0.10)$. Finally, $\mathrm{V}$ and $\mathrm{Cr}$ had very low values $(<0.1)$. The BAC value obtained for $\mathrm{Sr}$ in this study is similar to those reported in the scientific literature (Kabata-Pendias and Sadurski 2004). If we compare the results obtained in other studies carried out in Castilla-La Mancha (Amorós et al. 2012b; Bravo et al. 2017) it can be observed that the values for $\mathrm{Sr}$ and $\mathrm{Zn}$ are higher ( 0.56 vs. 0.28 and 0.7 vs. 0.37 , respectively); the values for $\mathrm{Ba}, \mathrm{V}, \mathrm{Cr}$ and $\mathrm{Cu}$ are lower (0.14 vs. $0.26 ; 0.06$ vs. 0.16 ; 0.07 vs. 0.17 and 0.19 vs 1.86 , respectively); while the value of $\mathrm{Pb}$ is similar (0.12 vs. 0.15$)$.

\section{Table 4}

The relationship between the concentrations of major and trace elements studied in soils and leaves from grapevine cultivars of Alcubillas are represented in Figure 2. It can be seen that the higher the soil contents in $\mathrm{Sr}, \mathrm{Pb}$ and $\mathrm{Cr}$, the higher the contents of the same elements incorporated in the leaves. Amorós et al. (2012b) found a positive correlation between the amount of Sr in the soil and that in the leaf and grape. A similar trend was observed for $\mathrm{Cu}, \mathrm{Zn}$ and, to a lesser extent, $\mathrm{Ba}$, but less markedly than for the previous elements. Finally, the content of $\mathrm{V}$ in the leaf decreases as the content in the soil increases.

All of these data provide relevant information that could help to ascertain the nutritional status of the plant. Nevertheless, significant correlarions were not found in this survey; the uptake of elements in grapevine can be influenced by soil, climate, geographic origin, and rootstock type.

\section{Figure 2}

The elementary compositions of the soils of Alcubillas allowed us to establish the pedogeochemical baseline levels and these are relevant because they allow the distinction of contaminated areas from uncontaminated ones. The absence of potentially polluting industrial activities in the area of study means that most of the potentially polluting chemical elements are at concentrations close to the pedogeochemical baseline levels of the region (Jimenez Ballesta et al. 2010), i.e., they are directly associated with the existing lithological units or weathering processes.

It should be noted that the foliar application of fungicides or the addition (direct or irrigated) of phosphate fertilizers (with impurities that contain heavy metals such as $\mathrm{Cd}, \mathrm{Hg}$ and $\mathrm{Pb}$, Ramalho et al. 1999; Nagajyoti et al. 2010) contribute to increased contents in soils, so it was expected that the vineyard soils of Alcubillas would have higher than normal contents in some PTEs. It is worth noting that $\mathrm{Cu}$ values have been reported for the soils of traditional wine regions throughout the world. For example, these values range from 20 to $500 \mathrm{mg} \cdot \mathrm{kg}^{-1} \mathrm{Cu}$ in France (Flores-Véles et al. 1996; Brun et al. 1998), 35 to $600 \mathrm{mg} \cdot \mathrm{kg}^{-1}$ in Spain (Arias et al. 2004), 2 to $375 \mathrm{mg} \cdot \mathrm{kg}^{-1}$ in Italy (Toselli et al. 2009), 100 to $210 \mathrm{mg} \cdot \mathrm{kg}^{-1}$ in Greece (Vavolidou et al. 2005) and 40 to $250 \mathrm{mg} \cdot \mathrm{kg}^{-1}$ in Australia (Pietrzak and Mcphail 2004). This is not the case for Alcubillas, where the common feature is the addition of organic residues that are mainly of plant origin (pruning residues) to which goat and sheep excrement is added.

In Alcubillas farmers are aware of this situation and they fertilize soils with only moderate doses with a low frequency of application. The farmers also control the changes that occur during the development and growth of the crop. In fact, even if the farmers are not aware of the origins, they observe structural, biochemical and physiological changes through visible symptoms of phytotoxicity such as reduced growth (especially of the root system), chlorosis and necrosis in the leaves.

On the basis of the $\mathrm{Cu}$ values found, one can expect shortening and thickening of the apex of the vine root (Ambrosini et al. 2015) along with an increase in the number of lateral roots and plasmolyis in the epidermis of some cells, thus reducing the density of the root hairs (Chen et al. 2013; Zhang et al. 2014). In addition, the presence of excess $\mathrm{Cu}$ in plant shoots can lead to a decrease in the concentration of photosynthetic 
pigments and the fixation rate of $\mathrm{C}$. These changes may in turn increase oxidative stress at the cellular level (Cambrollé et al. 2013). However, these symptoms were not observed in the studied area, because $\mathrm{Cu}$-fungicide applications are minimal to achieve desired effects. The farmer is aware of this and avoids incorporating products that contain $\mathrm{Cu}$.

\section{Conclusions}

The vineyard soils display a heterogeneous concentration in terms of elemental composition in the study area, with Ca being one of the most abundant major elements and S below the average world background values. The small differences between the concentrations of the elements with depth can be explained by assuming a common source that is primarily geogenic and pedogenic in nature followed by secondary factors of ploughing and agricultural practices.

Regarding the pedogeochemical baseline levels, and despite the fact that the use of fertilizers and pesticides in the vineyard is common, we can describe the trace element contents as normal for the investigated area, that is, trace element values associated with potential toxicity in soils were not found. Indeed, a risk assessment of the elementary composition of the soils indicated that this does not currently pose a high risk and that there are no adverse effects caused by PTEs accumulation in the soils. This is because the farmers are very sensitive to the environment and they aim to achieve only moderate yields of grapes per hectare.

The relationships between concentrations of elements in soil versus leaves indicate that the higher soil contents in $\mathrm{Sr}, \mathrm{Pb}$ and $\mathrm{Cr}$ imply higher contents of these elements in the leaves, while the $\mathrm{V}$ content decreases in leaf as it increases in the soil. It was found that some elements were not taken up by the Vitis vinifera, even though elements like $\mathrm{Zr}$ and $\mathrm{Rb}$ are present in relatively high concentrations in the soil.

In conclusion, the present study provides a reference for future analogous studies in other areas, particulary in a Mediterraenn environment, but additional research on trace element contents in grape clusters is required to understand better the transfer of trace elements from soil to products (grapes and wine).

\section{Acknowledgments}

The authors are indebted to the Denominación de Origen Valdepeñas, (Denomination of Origin), project number UCTR180065 for funding this project. Furthermore, the authors are also grateful to all farmers for the use of facilities during field work.

Conflicts of Interest: The authors declare no conflict of interest.

\section{References}

Abdi MR, Saraee KRE, Fard MR, Ghahfarokhi MB (2015) Potential health concerns of trace elements and mineral content in commonly consumed greenhouse vegetables in Isfahan, Iran. Adv Biomed Res. https://doi.org/10.4103/2277-9175.166152

Adriano DC (2001) Trace elements in terrestrial environments: biogeochemistry, bioavailability, and risks of metals. Springer Verlag

Amorós JA, García Navarro FJ, Pérez de los Reyes C, Bravo Martín-Consuegra S, Jiménez Ballesta R, Chacón JL, Martínez J (2012a) Effect of the grapevine variety in leaf trace element content from a calcareous soil in La Mancha, 5-21. IX Int. Terroirs Congress

Amorós JA, García Navarro FJ, Pérez C, Campos JA, Bravo S, Jiménez Ballesta R, García Moreno R (2012b) Geochemical influence of soil on leaf and grape (Vitis vinifera L. 'Cencibel') composition in La Mancha region (Spain). Vitis 51(3):111-118

Amorós JA, Pérez de los Reyes C, García Navarro FJ, Bravo S, Chacón JL, Martínez J, Jiménez Ballesta R (2013) Bioaccumulation of mineral elements in grapevine varieties cultivated in "La Mancha". J. Plant Nutr Soil Sci 1-8. https://doi.org/10.1002/jpln.201300015 
Amoros JA, Bravo S, Perez-de-los-Reyes C, García-Navarro FJ, Campos JA, Sanchez-Ormeno M, JimenezBallesta R, Higueras P (2017) Iron uptake in vineyard soils and relationships with other elements (Zn, Mn and Ca). The case of Castilla-La Mancha, Central Spain. Appl Geochem 1-6

Arias M, López E, Fernández D, Soto B (2004) Copper distribution and dynamics in acid vineyard soils treated with copper-based fungicides. Soil Sci 169:796-805

Bloemen ML, Markert B, Lieth H (1995) The distribution of Cd, Cu, Pb and $\mathrm{Zn}$ in topsoils of Osnabrück in relation to land use. Sci Total Environ 166:137-148

Bora FD, Bunea CI, Rusu T, Pop N (2015) Vertical distribution and analysis of micro-, macroelementsand heavy metals in the system soil-grapevine-wine in vineyard from North-West Romania. Chem. Central J 9:1-13

Bora FD, Pop TI, Mihaly L, Bunea CI., Pop N (2013) Research on the chemical composition of soil with pollutant effect in some vineyards from Northwestern Transylvania. Bull USAMV Hortic 70(1):53-59

Bradl H (2004) Adsorption of heavy metal ions on soils and soils constituents. J Colloid Interf Sci 277:1-18

Bravo S, Amorós JA, Pérez-De-Los-Reyes C, García FJ, Moreno MM, Sánchez-Ormeño M, Higueras P (2017) Influence of the soil $\mathrm{pH}$ in the uptake and bioaccumulation of heavy metal ( $\mathrm{Fe}, \mathrm{Zn}, \mathrm{Cu}, \mathrm{Pb}$ and $\mathrm{Mn}$ ) and other elements (Ca, K, Al Sr and Ba) in vine leaves, Castilla-La Mancha (Spain). J Geochem Explor 174:79-83

Brun LA, Maillet J, Richarte J, Hermann P, Remy JC (1998) Relationships between extractable copper, soil properties and copper uptake by wild plants in vineyard soils. Environ Pollut 102:151-161

Buccolieri A, Buccolieri G, Cardellicchio N (2006) Heavy Metals in Marine Sediments of Taranto Gulf (Ionian Sea, Southern Italy). Mar Chem 99:227-235. http://dx.doi.org/10.1016/j.marchem.2005.09.009

Burger A, Lichtscheidl I (2019) Strontium in the environment: Review about reactions of plants towards stable and radioactive strontium isotopes. Sci Total Environ 653:1458-1512. http://dx.doi.org/10.1016/j.scititenv.2018.10.312

Cambrollé L, García JL, Oocete R, Figueroa ME, Cantos M (2013) Growth and photosynthetic responses to copper in wild grapevine. Chemosphere 93:294-301

Chen PY, Lee YI, Chen BC, Juang KW (2013) Effects of calcium on rhizotoxicity and the accumulation and translocation of copper by grapevines. Plant Physiol Biochem 73:375-82

Chopin EIB, Marin B, Mkoungafoko R, Rigaux A, Hopgood M, Delannoy E, Cances B, Laurain M (2008) Factors affecting distribution and mobility of trace elements $(\mathrm{Cu}, \mathrm{Pb}, \mathrm{Zn}$ ) in a perennial grapevine (Vitis vinifera L.) in the Champagne region of France. Environ Pollut 156:1092-1098

Conde P, Martín Rubí JA, Jiménez Ballesta R (2008) Environmental evaluation of elemental cesium and strontium contents and their isotopic activity concentrations in different soils of La Mancha (Central Spain). Environ Geol 56(2):327-334. http://dx.doi.org/10.1007/s00254-007-1168-x

Evans JL, Barabash SJ (2010) Molybdenum, silver, thallium and vanadium. En: Hooda PS (ed.) Trace Elements in Soils, 1st edn. Wiley, Chichester pp 515-549

FAO-ISRIC-ISSS (2006) World Reference Base for Soil Resources.Food and Agriculture Organization of the United Nations. Rome

Fishel FM (2014) Pesticide toxicity profile: Copper-based Pesticides. University of Florida, Florida

Flores-Vélez LM, Ducaroir J, Jaunet AM, Robert M (1996) Study of the distribution of copper in an acid sandy vineyard soil by three different methods. Eur J Soil Sci 47:523-32

Geana I, Iordache A, Ionete R, Marinescu A, Ranca A, Culea M (2013) Geographical origin identification of Romanian wines by ICP-MS elemental analysis. Food Chem 138:1125-1134 
Greenough JD, Mallory-Greenough LM, Fryer BJ (2005) Geology and wine 9: regional trace element fingerprinting of Canadian wines. Geosci Can 32

Gu YG, Gao YP, Lin Q (2016) Contamination, bioaccessibility and human health risk of heavy metals in exposedlawn soils from 28 urban parks in southern China's largest city, Guangzhou. Appl Geochem 67:52-58. https://doi.org/10.1016/j.apgeochem.2016.02.004

Hooda P (2010) Trace elements in soils. John Willey and Soons Ltd., London

Huzum R, Iancu OG, Buzgar N (2012) Geochemical distribution of selected trace elements in vineyard soils from the Huși area, Romania. Carpath J Earth Environ Sci 7(3):61-70

Jiménez-Ballesta R, Conde P, Martín JA, García R (2010) Pedo-geochemical baseline content levels and soil quality reference values of trace elements in soils from the Mediterranean (Castilla-La Mancha, Spain). Cent Eur J Geosci 2(4):441-454

Jiménez-Ballesta R., Bravo S., Amorós J.A., Pérez-de los Reyes C., García-Pradas J. and García-Navarro F.J. (2020). Understanding the Quality of Local Vineyard Soils in Distinct Viticultural Areas: A Case Study in Alcubillas (La Mancha, Central Spain). Agriculture 10, 66; doi:10.3390/agriculture10030066.

Kabata-Pendias A (2011) Trace Elements in Soils and Plants. CRC Press, Boca Raton

Kabata-Pendias A, Sadurski W (2004) Trace elements and compounds in soil. In: Merian E, Anke M, Ihnat M, Stoeppler M (Eds) Elements and Their Compounds in the Environment, 2nd edn. Wiley-VCH, Weinheim, pp 79-99

Kment P, Mihaljevic M, Ettler V, Sebek O, Strnad L, Rohlova L (2005) Differentiation of Czech wines using multielement composition. A comparison with vineyard soil. Food Chem 91:157-165. https://doi.org/10.1016/j.foodchem.2004.06.010

Komárek M, Čadková E, Chrastný V, Bordas F, Bollinger JC (2010) Contamination of vineyards soils with fungicides: A review of environmental and toxicological aspects. Environ Int 36:138-151

Luo D, Zheng H, Cheng Y, Wang G, Ding F (2010) Transfer characteristics of cobalt from soil to crops in the suburban areas of Fujian Province, Southeast China. J Environ Manag 91(11):2248-2253

Maltman A (2013) Minerality in wine: a geological perspective. J Wine Res 24:169-181

McBride MB (1994) Environmental chemistry of soils. University Oxford Press, New York

Mîrlean N, Roisenberg A, Chies JO (2007) Metal contamination of vineyard soils in the wet subtropics (southern Brazil). Environ Pollut 149:10-17

Mishra P, Singh SK, Srivastava PC, Singh S (2006) Distribution of molybdenum and boron in some soils of northern alluvial plain of UP and Uttaranchal in relation to soil characteristics. Agropedol 16(1):60-62

Moreno IM, González-Weller D, Gutierrez V, Marino M, Cameán AM, González AG, Hardisson A (2007) Differentiation of two Canary DO red wines according to their metal content from inductively coupled plasma optical emission spectrometry and graphite furnace atomic absorption spectrometry by using probabilistic neural networks. Talanta 72:263-268

Muller G (1969) Index of Geo-Accumulation in Sediments of the Rhine River. GeoJ 2:108-118

Nagajyoti PC, Lee KD, Sreekanth TVM (2010) Heavy metals, occurrence and toxicity for plants: a review. Environ Chem Lett 8:199-216

Peris M, Micò C, Recatalá L, Sánchez R, Sánchez J (2007) Heavy metal contents in horticular crops of a representative area of the European Mediterranean region. Sci Total Environ 378:42-48 
Pessanha S, Carvalho ML, Becker M, Von Bohlen A, (2010) Quantitative determination on heavy metals in different stages of wine production by Total Reflection X-ray Fluorescence and Energy Dispersive X-ray Fluorescence: Comparison on two vineyards. Spectrochim Acta Part B 65:504-507

Pietrzak U, Mcphail DC (2004) Copper accumulation, distribution and fractionation in vineyard soils of Victoria, Australia. Geoderma 122:151-66

Pohl P (2007) What do metals tell us about wine? Trends Anal. Chem 26: 941-949

Protano G, Rossi S (2014) Relationship between soil geochemistry and grape composition in Tuscany (Italy). J Plant Nutr Soil Sci 177:500-508

Ramalho JFGP, Amaral Sobrinho NMB, Velloso ACX (1999) Acúmulo de metais pesados em solos cultivados com cana de açúcar pelo uso contínuo de adubação fosfatada e água de irrigação. Rev Bras Ciênc Solo 2:971979

Reis AP, Menezes de Almeida L, Ferreira da Silva E, Sousa AJ, Patinha C, Fonseca EC (2007) Assessing the geochemical inherent quality of natural soils in the Douro river basin for grapevine cultivation using data analysis and geostatistics. Geoderma 141:370-383

Romic M, Romic D (2003) Heavy Metals Distribution in Agricultural Topsoils in Urban Area. Environ Geol 43:795-805. https://doi.org/10.1007/s00254-002-0694-9

Schwarz G, Belaidi AA (2013) Molybdenum in human health and disease. Met Ions Life Sci 13:415-50. https://doi.org/10.1007/978-94-007-7500-8_13.

Soil Survey Staff (2014) Keys to Soil Taxonomy. USDA-Natural Resources Conservation Service, Washington $\mathrm{DC}$

Toselli M, Baldi E, Marcolini G, Malaguti D, Quartieri M, Sorrenti G, Marangoni B (2009) Response of potted grapevines to increasing soil copper concentration. Aust J Grape Wine Res 15:85-92

Tóth G, Hermann T, Da Silva MR, Monatanarella L (2016) Heavy metals in agricultural soils of the European Union with implications for food safety. Environ Pollut 88:299-309. http://doi.org/10.1016/j.envint.2015.12.017.

Ungureanu T, Iancu GO, Pintilei M, Chicoș MM (2017) Spatial distribution and geochemistry of heavy metals in soils: A case study from the NE area of Vaslui county, Romania. J Geochem Explor 176:20-32

Vavoulidou E, Avramides EJ, Papadopoulos P, Dimirkou A, Charoulis A, Konstantinidou-Doltsinis S (2005) Copper content in agricultural soils related to cropping systems in different regions of Greece. Commun Soil Sci Plant Anal 36:759-73

Wightwick AM, Reichman SM, Menzies NW, Allinson G (2013) Industry wide risk assessment: acase study of $\mathrm{Cu}$ in Australian Vineyards Soils. Water Air Soil Pollut. 224(1702):1-8

Zhang L, Pan Y, Lv W, Xiong ZT (2014) Physiological responses of biomass allocation, root architecture, and invertase activity to copper stress in young seedlings from two populations of Kummerowiastipulacea (maxim.) Makino. Ecotoxicol Environ Saf 104:278-84

\section{Hosted file}

Figure 1.pdf available at https://authorea.com/users/378936/articles/495329-macro-andmicroelements-occurence-in-soil-and-plant-leaves-samples-of-a-representative-andpotentially-sustainable-mediterranean-vineyard

\section{Hosted file}

Figure 2.pdf available at https://authorea.com/users/378936/articles/495329-macro-andmicroelements-occurence-in-soil-and-plant-leaves-samples-of-a-representative-and- 
potentially-sustainable-mediterranean-vineyard

\section{Hosted file}

Table 1.pdf available at https://authorea.com/users/378936/articles/495329-macro-andmicroelements-occurence-in-soil-and-plant-leaves-samples-of-a-representative-andpotentially-sustainable-mediterranean-vineyard

\section{Hosted file}

Table 2.pdf available at https://authorea.com/users/378936/articles/495329-macro-andmicroelements-occurence-in-soil-and-plant-leaves-samples-of-a-representative-andpotentially-sustainable-mediterranean-vineyard

\section{Hosted file}

Table 3.pdf available at https://authorea.com/users/378936/articles/495329-macro-andmicroelements-occurence-in-soil-and-plant-leaves-samples-of-a-representative-andpotentially-sustainable-mediterranean-vineyard

\section{Hosted file}

Table 4.pdf available at https://authorea.com/users/378936/articles/495329-macro-andmicroelements-occurence-in-soil-and-plant-leaves-samples-of-a-representative-andpotentially-sustainable-mediterranean-vineyard 